\title{
Genital warts and infection with human immunodeficiency virus in high-risk women in Burkina Faso: a longitudinal study
}

Andrea J Low ${ }^{1 *}$, Tim Clayton ${ }^{1}$, Issouf Konate ${ }^{2}$, Nicolas Nagot ${ }^{3}$, Abdoulaye Ouedraogo ${ }^{1}$, Charlotte Huet ${ }^{2}$, Marie-Noelle Didelot-Rousseau ${ }^{3}$, Michel Segondy ${ }^{3}$, Philippe Van de Perre ${ }^{3}$, Philippe Mayaud ${ }^{1,2}$, the Yérélon Cohort Study Group

\begin{abstract}
Background: Human papillomaviruses are the most common sexually transmitted infections, and genital warts, caused by HPV-6 and 11, entail considerable morbidity and cost. The natural history of genital warts in relation to HIV-1 infection has not been described in African women. We examined risk factors for genital warts in a cohort of high-risk women in Burkina Faso, in order to further describe their epidemiology.

Methods: A prospective study of 765 high-risk women who were followed at 4-monthly intervals for 27 months in Burkina Faso. Logistic and Cox regression were used to identify factors associated with prevalent, incident and persistent genital warts, including HIV-1 serostatus, CD4+ count, and concurrent sexually transmitted infections. In a subset of 306 women, cervical HPV DNA was tested at enrolment.

Results: Genital wart prevalence at baseline was 1.6\% (8/492) among HIV-uninfected and 7.0\% (19/273) among HIV-1 seropositive women. Forty women (5.2\%) experienced at least one incident GW episode. Incidence was 1.1 per 100 person-years among HIV-uninfected women, 7.4 per 100 person-years among HIV-1 seropositive women with a nadir CD4+ count $>200$ cells/ $\mu \mathrm{L}$ and 14.6 per 100 person-years among HIV-1 seropositive women with a nadir CD4+ count $\leq 200$ cells/ $\mu \mathrm{L}$. Incident genital warts were also associated with concurrent bacterial vaginosis, and genital ulceration. Antiretroviral therapy was not protective against incident or persistent genital warts. Detection of HPV-6 DNA and abnormal cervical cytology were strongly associated with incident genital warts.

Conclusions: Genital warts occur much more frequently among HIV-1 infected women in Africa, particularly among those with low CD4+ counts. Antiretroviral therapy did not reduce the incidence or persistence of genital warts in this population.
\end{abstract}

\section{Background}

Human papillomaviruses (HPV) are the most common sexually transmitted infections (STI) worldwide, although they are often asymptomatic [1]. HPV infection is usually transient, [2] but persistence depends on HPV type and host immune status [3,4]. HPV types are divided into high-risk (HR-HPV)and low-risk (LR-HPV), depending on their potential for causing cervical and other ano-genital cancers [5]. The LR-HPV types HPV-6 and HPV-11 cause significant morbidity as the predominant causes of

\footnotetext{
* Correspondence: andrea.low@lshtm.ac.uk

'London School of Hygiene \& Tropical Medicine, London, UK

Full list of author information is available at the end of the article
}

genital warts (GWs) [6,7]. Comparatively little is known about the epidemiology and natural history of LR-HPV infection and GWs in sub-Saharan Africa. LR-HPV prevalence shows considerable regional variation, such as $11 \%$ in the Gambia, [8] or $28 \%$ in Tanzania, [9] and is higher among individuals infected with the human immunodeficiency virus (HIV) [10].

HIV infection is known to alter the natural history of HPV infection. Patients co-infected with HIV-1 and HPV have a greater likelihood of HPV progression, with an increased risk for development of cervical neoplasia in immunosuppressed women [11]. HIV-1 infected patients with GWs can experience florid and prolonged

\section{Biomed Central}

(C) 2011 Low et al; licensee BioMed Central Ltd. This is an Open Access article distributed under the terms of the Creative Commons Attribution License (http://creativecommons.org/licenses/by/2.0), which permits unrestricted use, distribution, and reproduction in any medium, provided the original work is properly cited. 
clinical manifestations driven by an impaired CD4+ T-lymphocyte response and other forms of immune dysfunction $[12,13]$. Low $\mathrm{CD} 4+$ count $(\leq 200$ cells $/ \mu \mathrm{L})$ is the strongest independent predictor of infection with HRHPV genotypes and is also associated with an increased risk of GWs $[13,14]$. The impact of highly active antiretroviral therapy (HAART) on GWs remains uncertain, with different statistical designs revealing different effects on incidence and persistence $[3,15]$. Other possibly contributing factors to GWs, such as other sexually transmitted or reproductive tract infections (STI/RTI), are poorly understood. Some studies suggest that STI/ RTI increase the acquisition of HPV. However, these data are limited and predominantly from Western populations $[13,15]$.

We have established a cohort of women at high risk for HIV and other STI/RTI in Burkina Faso, providing an opportunity to examine the epidemiology of various STI/RTI over a three-year period. The aims of this study were to determine the prevalence, incidence and persistence of GWs, and their association with HIV infection, immunosuppression, and other risk factors in an African setting.

\section{Methods}

\section{Participants and study procedures}

The Yérélon Cohort was established in 1998 to examine factors associated with HIV infection among professional female sex workers and other high-risk women in Burkina Faso and to design interventions to prevent infection. A new phase of enrolment began in December 2003 and continued until January 2005. Women were eligible for enrolment if they declared a history of at least one transactional sex act per week, were aged 16 years or older, and were willing to undergo HIV testing. Some women were recruited from local organizations for people living with HIV/AIDS, using the same criteria. All women provided written informed consent. The Yérélon Cohort research protocol was approved by the institutional review board at Centre Muraz, and the research ethics committees at the Burkina Faso Ministry of Health and the London School of Hygiene \& Tropical Medicine.

Participants were followed approximately every 4 months until February 2006 for a maximum of 6 follow-up visits. At enrolment, an interviewer administered a questionnaire eliciting socio-demographic and behavioral characteristics, and sexual health information. At subsequent visits, intervening behavioral, sexual health and treatment information was collected. At all visits a study clinician performed a full physical exam and collected genital samples. Clinicians documented the presence of abnormal discharge, genital ulcers, and GWs, which were defined as a genital proliferation with the clinical appearance of condylomata acuminata [15]. The genital sites were described as the cervix, vagina, labia, or 'external' (outer pubic and anal) areas. Patients were treated for STI/RTI according to national guidelines; there was no treatment available for GWs. Since April 2004, HIV-infected participants meeting the World Health Organization (WHO) eligibility criteria for HAART initiation in developing countries have been provided with antiretrovirals [16]. Women with HIV clinical stages III or IV or with a CD $4+$ count $\leq 200$ cells $/ \mu \mathrm{L}$ were treated with standard antiretroviral therapy, primarily zidovudine (AZT), lamivudine (3TC) and efavirenz (EFV). Women already on HAART at the enrolment visit had been provided with medications at the Bobo-Dioulasso University Hospital.

\section{Laboratory investigations}

Vaginal smears were examined using wet-mount microscopy to detect Trichomonas vaginalis (TV) and Gramstained to diagnose bacterial vaginosis (BV) [17]. Diagnosis of Neisseria gonorrhoeae was made by culture of cervical swabs using modified Thayer-Martin media. Chlamydia trachomatis diagnosis could not be performed during the study, but has been shown to be rare in this population [18].

Blood samples were collected at enrolment and then every 4 months. Syphilis serostatus was determined every 12 months using the rapid plasma reagin test (RPR, Human GmbH) confirmed with a Treponema pallidum haemagglutination assay (TPHA, Newmarket Laboratories). HSV-2 serology was done using the Kalon IgG2-ELISA test (Kalon Biologicals). HIV serology was done at enrolment and every 4 months among seronegative women using a Determine- $1 / 2$ rapid testing kit (Abbott Laboratories) with Genie-II (Bio-Rad Laboratories) confirmation. CD4+ counts were determined using FACScan (Becton Dickinson) at enrolment and every 6 months among HIV-1 seropositive women; plasma HIV-1 RNA was quantified every 6 to 12 months using real-time PCR with a lower limit of detection of $300\left(2.48 \log _{10}\right)$ copies/mL [19]. Values were converted to $\log _{10}$ copies $/ \mathrm{mL}$; those below the threshold of detection were assigned a value of half the threshold.

A subset of women enrolled between December 2003 and March 2004 submitted an additional cervical swab at enrolment for HPV DNA detection and liquid-based cytology using a Cervex swab and the ThinPrep 2000 processor (Cytyc Corporation) [10]. HPV genotyping was performed using the INNO-LiPA genotyping v2 test (Innogenetics) [20]. The 2001 Bethesda classification was used for Papanicolaou-stained cervical slides interpretation [21]. 


\section{Definitions}

Prevalent GWs were defined as the presence of clinically-defined condylomata acuminata at the enrolment visit. Due to the small number of women with CD4+ counts at the enrolment visit, women were classified as HIV seronegative and HIV-1 seropositive at baseline. Incident GWs were defined as the first documented occurrence of condylomata acuminata in a previously undocumented site after the enrolment visit. Women with a GW in one location who developed a lesion in a new location were included as a new incident event. Persistent GWs were defined as GWs present in the same anatomical site for at least two consecutive visits, which could include the enrolment visit. Women were stratified during study follow-up according to their nadir CD4+ count in the following categories: (i) HIVnegative, (ii) $\mathrm{HIV}-1$ positive with a nadir CD4+ count $>200$ cells $/ \mu \mathrm{L}$, and (iii) $\mathrm{HIV}-1$ positive with a nadir CD4 + count $\leq 200$ cells $/ \mu \mathrm{L}$.

\section{Statistical analysis}

Analyses examined the association between HIV status and other potential risk factors with prevalent GWs. Univariate associations were examined using chisquared tests for categorical variables and two-sample t-tests for continuous variables. Due to the strong associations between many of our variables of interest, a multivariate logistic regression model was developed in a stepwise fashion including HIV status and risk factors either decided a priori or independently associated with prevalent GWs using $\mathrm{p}<0.05$ as the inclusion criterion.

We measured incidence and persistence of GWs and determined associations of potential risk factors with these outcomes using Cox regression. To allow for intra-subject correlation, these models used shared frailty [22]. Other potential risk factors included timeupdated measures, such as concurrent STI/RTI, use of HAART, and behavioral measures recorded at follow-up visits. In order to establish the most likely ordering of events, measures of behavior and confirmed STI/RTI over the preceding period were taken from the visit at which incident or persistent GWs were identified and serological time-updated measures were taken from the visit preceding any visit at which a new GW was identified. For HIV-1 seropositive women, a separate model was constructed which included CD4+ count and HAART use at the prior visit and maximum viral load during the study period. Nadir CD4+ count was not included in these models because model convergence could not be achieved.

Further analyses were conducted to examine the association of cervical HPV and squamous intraepithelial lesions (SIL) with incident GWs among women from whom cervical HPV DNA had been collected, using the same methods as above to construct the final model.

The effect of time in the study was assessed for each variable in all models and an interaction parameter was included if the hazard ratio changed significantly after one year of follow-up.

Statistical analyses were performed using Stata version10.0 (StataCorp).

\section{Results}

\section{Characteristics of cohort participants}

Overall, 767 women were enrolled in the Yérélon Cohort study between December 2003 and January 2005, and followed up until February 2006. Two hundred and sixty eight (34.9\%) women were infected with HIV-1 and five $(0.7 \%)$ were co-infected with HIV-1 and HIV-2. Two women were infected with HIV-2 alone, and were excluded from analyses. Characteristics of study participants at enrolment are presented in Table 1. Overall mean age was 28 years (range, 15-54). The median follow-up time was 1.7 years (range $0-2.2$ years). At baseline, a quarter $(24.7 \%, 66 / 267)$ of $\mathrm{HIV}-1$ seropositive women had a CD $4+$ count $<200$ cells $/ \mu \mathrm{L}$ and $9.5 \%$ $(26 / 273)$ of women were on HAART. HIV-1 infected women were significantly older, were more likely to have been married, had fewer recent sexual partners and were less likely to use hormonal contraception. No women were infected with Neisseria gonorrhoeae.

In the analysis of the 306 women from whom cervical cytological samples were collected, HIV-1 seropositive women had significantly more cervical squamous intraepithelial lesions than HIV-uninfected women $(\mathrm{P}<0.001)$ (Table 1). There were no cases of atypical squamous cells-cannot exclude HSIL (ASC-H), atypical glandular cells (AGC), or cancer identified.

\section{Prevalent genital warts and associated risk factors}

At enrolment, 27 women (3.5\%) had GWs, 1.6\% (8/492) among HIV-uninfected and 7.0\% (19/273) among HIV-1 seropositive women $(\mathrm{P}<0.001)$ (Table 1$)$. There were no prevalent GWs among the 26 women taking HAART. In the multivariate analysis, which included HSV-2 serostatus, the presence of bacterial vaginosis, number of recent sexual partners and age group, there was a 5-fold increase in risk for prevalent GWs in HIV1 seropositive women (adjusted odds ratio [aOR] 5.33, 95\%CI: 1.97 to $14.40, \mathrm{P}=0.001)$. Women who smoked had a 3-fold increased risk of prevalent GW (aOR 3.55, 95\%CI: 1.03 to $12.32, \mathrm{P}=0.05)$. For HIV-1 seropositive women, there was no evidence of a relationship between CD4+ count and prevalence of GWs (CD4+ count >200 cells $/ \mu \mathrm{L}$ vs. $\leq 200$ cells $/ \mu \mathrm{L},[\mathrm{aOR}=1.77,95 \% \mathrm{CI}: 0.36$ to $8.61, \mathrm{P}=0.48)$. None of the other variables shown in Table 1 were associated with prevalent GWs. 
Table 1 Characteristics of 765 high-risk women at cohort enrolment, according to HIV-1 serostatus

\begin{tabular}{|c|c|c|c|}
\hline Characteristic & HIV seronegative $(\mathrm{N}=492) \mathrm{n}(\%)$ & HIV-1 seropositive $(\mathrm{N}=273)$ n (\%) & P-value \\
\hline \multicolumn{4}{|l|}{ Age groups, years $(\mathrm{N}=759)$} \\
\hline $16-24$ & $265(54.1)$ & $53(19.7)$ & $<0.001^{\mathrm{b}}$ \\
\hline $25-34$ & $138(28.2)$ & $124(46.1)$ & \\
\hline$\geq 35$ & $87(17.8)$ & $92(34.2)$ & \\
\hline \multicolumn{4}{|l|}{ Education ( $\mathrm{N}=752$ ) } \\
\hline None & $189(38.8)$ & $116(44.8)$ & 0.19 \\
\hline Primary or above & $298(61.2)$ & $149(56.2)$ & \\
\hline \multicolumn{4}{|l|}{ Marital status $(N=754)$} \\
\hline Widowed & $14(2.9)$ & $55(20.8)$ & $<0.001^{a}$ \\
\hline Divorced/Separated & $70(14.3)$ & $50(18.9)$ & \\
\hline Married/cohabitating & $88(18.0)$ & $58(21.9)$ & \\
\hline Single & $317(64.8)$ & $102(38.5)$ & \\
\hline Age at first sex, median (IQR), years & $16(15-18)$ & $16(15-18)$ & $0.42^{\mathrm{b}}$ \\
\hline \multicolumn{4}{|c|}{ Number of sex partners in last week $(N=752)$} \\
\hline None & $110(22.5)$ & $114(43.2)$ & $<0.001^{\mathrm{b}}$ \\
\hline $1-9$ & $309(63.3)$ & $120(45.5)$ & \\
\hline$\geq 10$ & $69(14.1)$ & $30(11.4)$ & \\
\hline Currently smoking ( $N=759$ ) & $25(5.1)$ & $19(7.0)$ & 0.30 \\
\hline \multicolumn{4}{|l|}{ Contraceptive use ( $N=760$ ) } \\
\hline Other/None & $405(83.2)$ & $249(91.2)$ & 0.002 \\
\hline Hormonal contraception & $68(14.0)$ & $19(7.0)$ & \\
\hline Injectable contraception & $14(2.8)$ & $5(1.8)$ & \\
\hline Practices regular vaginal douching & $424(86.2)$ & $222(81.3)$ & 0.24 \\
\hline \multicolumn{4}{|l|}{ Condom use with clients/partners $(\mathrm{N}=751)$} \\
\hline Sometimes/Never & $177(36.0)$ & $98(35.9)$ & \\
\hline Always & $315(64.0)$ & $175(64.1)$ & 0.98 \\
\hline Current genital warts & $8(1.6)$ & $19(7.0)$ & $<0.001$ \\
\hline Bacterial vaginosis $(\mathrm{N}=718$ ) & $178(37.2)$ & $118(49.2)$ & 0.003 \\
\hline Trichomonas vaginalis $(N=596)$ & $29(7.2)$ & $19(9.6)$ & 0.32 \\
\hline HSV-2 positive serology $(\mathrm{N}=689)$ & $226(49.6)$ & $204(88.3)$ & $<0.001$ \\
\hline Current antiretroviral therapy (HAART) & & $26(9.5)$ & \\
\hline \multicolumn{4}{|l|}{ CD4+ count, cells/uL : } \\
\hline \multicolumn{4}{|l|}{ Not on HAART $(\mathrm{N}=242)$} \\
\hline$>500$ & & $81(33.5)$ & $0.09^{\mathrm{a}, \mathrm{e}}$ \\
\hline $200-500$ & & $105(43.4)$ & \\
\hline$<200$ & & $56(23.1)$ & \\
\hline \multicolumn{4}{|l|}{ On HAART ( $\mathrm{N}=25)$} \\
\hline$>500$ & & $4(16.0)$ & \\
\hline $200-500$ & & $11(44.0)$ & \\
\hline$<200$ & & $10(40.0)$ & \\
\hline \multicolumn{4}{|l|}{ Plasma HIV-1 RNA, $\log _{10}$ copies $/ \mathrm{mL}$ d: } \\
\hline \multicolumn{4}{|l|}{ Not on HAART ( $N=233)$} \\
\hline$\geq 2.48$ & & $204(87.6)$ & $<0.001^{a, e}$ \\
\hline$<2.48$ & & $29(12.4)$ & \\
\hline \multicolumn{4}{|l|}{ On HAART $(\mathrm{N}=24)$} \\
\hline$\geq 2.48$ & & $7(29.2)$ & \\
\hline$<2.48$ & & $17(70.82)$ & \\
\hline Cervical HPV-6 or $-11(\mathrm{~N}=306)^{f}$ & $13(7.1)$ & $15(12.2)$ & 0.13 \\
\hline $\operatorname{LSIL}(N=306)^{f}$ & $17(9.4)$ & $48(41.4)$ & $<0.001$ \\
\hline $\mathrm{HSIL}(\mathrm{N}=306)^{f}$ & $1(0.6)$ & $11(9.5)$ & \\
\hline
\end{tabular}

IQR, interquartile range; HAART, highly active antiretroviral therapy; Cl, confidence interval; HPV, human papillomavirus; LSIL/HSIL, low/high grade squamous intraepithelial lesions.

${ }^{\text {a }}$ Determined by $\chi^{2}$ analysis; ${ }^{b}$ Determined by $\chi^{2}$ test of trend; ${ }^{c}$ Nonparametric equality of medians test; ${ }^{\text {d }}$ Lower limit of detection of HIV-1 PVL is 2.48 log 10 copies $/ \mathrm{mL}{ }^{\mathrm{e}}$ Comparison of women on HAART vs not on HAART; ${ }^{f}$ Conducted in subset of women. 


\section{Incident genital warts and associated risk factors}

Over the 27 months of the study, 16.9\% (129/765) of women were lost to follow-up. Twenty-one women died, all of whom were HIV-1 seropositive. The percentage of scheduled visits attended was $83.3 \%$; this did not differ by HIV-1 serostatus.

Forty women (5.2\%) experienced at least one incident GW episode for a total of 50 episodes. The most common sites for new lesions were the external genitalia (including the perianal area) observed in 28 women. GW incidence was 1.1 per 100 person-years among HIV-uninfected women, 7.4 per 100 person-years among HIV-1 seropositive women with a nadir CD4+ count $>200$ cells $/ \mu \mathrm{L}$ and 14.6 per 100 person-years among HIV-1 seropositive women with a nadir CD4+ count $\leq 200$ cells $/ \mu \mathrm{L}$ (Table 2 ). Incidence was 16.7 per 100 person-years for women on HAART.

In the multivariate model including all women, HIV-1 and nadir CD4+ count were the strongest predictors of incident GWs. Compared to HIV-uninfected women, HIV-1-seropositive women with a nadir CD $4+\leq 200$ cells/ $\mu \mathrm{L}$ had an almost 20 -fold higher risk of incident GWs (adjusted hazard ratio [aHR] 19.13, 95\%CI: 6.94 to 52.71, $\mathrm{P}<0.001)$; among HIV-1-seropositive women with CD4+ counts $>200$ cells $/ \mu \mathrm{L}$, the estimated risk was 6-fold higher (aHR 6.51, 95\% CI: 2.38 to 17.78, $\mathrm{P}<$ $0.001)$. Having a primary education or above was protective (aHR 0.45, 95\%CI: 0.23 to $0.88, \mathrm{P}=0.02$ ). For the time-updated variables, concurrent bacterial vaginosis (aHR 2.17, 95\%CI: 1.13 to $4.18, \mathrm{P}=0.02$ ), and genital ulceration (aHR 3.29, 95\% CI: 1.13 to $9.55, \mathrm{P}=0.03$ ) were associated with incident GWs.

The model among HIV-1 seropositive women indicated a trend towards a protective effect for increasing CD4+ count at the prior visit (aHR 0.79 for each 100 cells $/ \mu \mathrm{L}$ increase, $95 \% \mathrm{CI}$ : 0.61 to $1.02, \mathrm{P}=0.07$ ), but the use of HAART per se was not protective. High maximum HIV-1 plasma viral load was predictive of incident GWs, although this was not statistically significant. There was no evidence of an interaction between nadir CD4+ count and time since enrolment on incidence of GWs.

\section{Persistence of genital warts}

In the absence of treatment, $40 \%$ of women with an identified GW (16/40) had persistent warts at the next visit. The strongest predictor of GW persistence was HIV-1 status and nadir CD4+ count: GW persistence was 0.4 per 100 person-years among HIV-uninfected women, 6.1 per 100 person-years among HIV-1 seropositive women with nadir CD $4+$ counts $>200$ cells $/ \mu \mathrm{L}$, and 13.4 per 100 person-years for those women with nadir $C D 4+$ counts $\leq 200$ cells $/ \mu \mathrm{L}$. The multivariate model among HIV-1 seropositive women indicated that there was no protective effect of prior antiretroviral treatment on persistence (aHR 1.71, 95\%CI: 0.40 to 7.23 , $\mathrm{P}=0.47$ ), but there was weak evidence that a CD4+ count was protective (aHR 0.72 for each 100 cells $/ \mu \mathrm{L}$ increase, $95 \% \mathrm{CI}: 0.45$ to $1.14, \mathrm{P}=0.16)$. No other factors were significantly associated with persistence of GWs.

\section{Association of HPV-6 or -11 with incident genital warts}

In the subgroup of 306 women with enrolment cytological and HPV DNA samples, HPV-52, a HR-HPV, was the most common HPV type, identified in $14.7 \%$ (45/ 306) of women. LR-HPV prevalence was $32.7 \%$ (100/ $306)$; the prevalence of HPV-6 and -11 were $6 \%(18 /$ $306)$ and $4 \%(13 / 306)$, respectively, and $71 \%(20 / 28)$ of women with HPV-6 or -11 were infected with more than one type of HPV. Detection of cervical HPV-6 DNA was associated with prevalent GWs (aOR 4.12, 95\%CI: 1.17 to $14.53, \mathrm{P}=0.03$ ) and had a strong predictive effect for incident GWs (aHR 9.09, 95\% CI: 1.75 to $47.29, \mathrm{P}=0.009$ ) during the first year of follow-up, compared to those without HPV-6 (Table 3). In fact, $44.4 \%$ $(8 / 18)$ of the women who were positive for cervical HPV-6 DNA had either a prevalent or incident GWs during the study period. In the analysis of individual HPV types, there was weak evidence of an association between incident GWs and cervical HPV-52 DNA at enrolment (aHR 3.81, 95\% CI: 0.90 to $16.23, \mathrm{P}=0.07$ ), with one lesion occurring in a woman co-infected with HPV-6. There was no evidence for any association between GWs and other HPV types, including HPV-11, although numbers were very small. The presence of abnormal cervical cytology (LSIL or higher) at enrolment was also predictive of incident GWs (aHR 3.05, 95\% CI: 1.17 to $7.92, \mathrm{P}=0.02$ ); these relationships did not vary with time. None of the women negative for HPV DNA at baseline had an incident event. The relationship between HIV-1 status and incident GWs persisted after adjusting for the presence of HPV-6 or -11 at baseline. HAART did not protect against incident lesions (aHR 1.03, 95\%CI: 0.26 to 4.05, $\mathrm{P}=0.96$ ).

\section{Discussion}

This study provides the first longitudinal data on the natural history of GWs among HIV infected women in Africa. In this setting, we found an overall prevalence of GWs of $3.5 \%$. This is consistent with GW prevalence from other countries in Africa, [24] although this depends on the region, prevalence of HIV-1, and the sexual risk behaviours of studied populations. The Women's Interagency HIV Study in the USA reported GW incidences of 2.2 per 100 person-years in HIV-uninfected and 8.9 per 100 personyears in HIV-1 seropositive women, which are similar to our findings [13]. 
Table 2 Univariate and multivariate assessment of factors associated with incident genital warts over three years

\begin{tabular}{|c|c|c|c|c|}
\hline Characteristic & $\begin{array}{l}\text { Number of events/ } \\
\text { person-years }\end{array}$ & $\begin{array}{c}\text { Unadjusted } \mathrm{HR}^{\mathrm{a}} \\
(95 \% \mathrm{Cl})\end{array}$ & $\begin{array}{l}\text { Adjusted } \mathrm{HR}^{\mathbf{b}} \\
(95 \% \mathrm{Cl})\end{array}$ & P-value \\
\hline \multicolumn{5}{|l|}{ 1. Among all women: } \\
\hline \multicolumn{5}{|l|}{ HIV status, nadir CD4+ count } \\
\hline HIV seronegative & $8 / 756$ & 1.0 & 1.0 & \\
\hline HIV-1+, CD4 >200cells/ $\mu \mathrm{L}$ & $18 / 245$ & $7.29(3.0-17.70)$ & $6.51(2.38-17.78)$ & $<0.001$ \\
\hline HIV-1+, CD4 $\leq 200$ cells $/ \mu \mathrm{L}$ & $24 / 165$ & $14.92(6.21-35.85)$ & $19.13(6.94-52.71)$ & $<0.001$ \\
\hline \multicolumn{5}{|l|}{ Enrolment variables: } \\
\hline \multicolumn{5}{|l|}{ Age groups, years } \\
\hline $16-24$ & $9 / 454$ & 1.0 & 1.0 & \\
\hline $25-34$ & $28 / 414$ & $3.29(1.40-7.74)$ & $1.74(0.69-4.42)$ & 0.24 \\
\hline$>34$ & $13 / 294$ & $2.19(0.84-5.72)$ & $0.83(0.29-2.37)$ & 0.73 \\
\hline \multicolumn{5}{|l|}{ Education } \\
\hline None & $32 / 510$ & 1.0 & & \\
\hline Primary/Above & $18 / 655$ & $0.43(0.22-0.86)$ & $0.45(0.23-0.88)$ & 0.02 \\
\hline \multicolumn{5}{|l|}{ Age at first sex, years } \\
\hline $10-17$ & $41 / 889$ & 1.0 & & \\
\hline $18-29$ & $9 / 275$ & $0.71(0.30-1.67)$ & & \\
\hline Smoking & $5 / 63$ & $1.76(0.50-6.15)$ & $1.56(0.50-4.86)$ & 0.44 \\
\hline HSV-2 positive serology & $43 / 676$ & $4.33(1.81-10.38)$ & $0.86(0.31-2.38)$ & 0.77 \\
\hline History of pregnancy & $47 / 954$ & $3.42(0.96-12.16)$ & $1.30(0.33-5.11)$ & 0.71 \\
\hline \multicolumn{5}{|l|}{ Concurrent variables: } \\
\hline \multicolumn{5}{|l|}{ Number of sex partners in past week } \\
\hline 0 & $10 / 241$ & 1.0 & 1.0 & \\
\hline $1-9$ & $30 / 753$ & $1.05(0.48-2.27)$ & $1.46(0.66-3.22)$ & 0.35 \\
\hline$\geq 10$ & $10 / 116$ & $2.44(0.85-7.05)$ & $3.16(1.11-8.95)$ & 0.03 \\
\hline \multicolumn{5}{|l|}{ Contraceptive use } \\
\hline None/Other & $40 / 958$ & 1.0 & 1.0 & \\
\hline Hormonal contraception & $4 / 156$ & $0.64(0.21-1.94)$ & $0.85(0.28-2.61)$ & 0.77 \\
\hline Injectable contraception & $4 / 34$ & $2.95(0.81-10.75)$ & $3.24(0.91-11.51)$ & 0.07 \\
\hline Practices regular vaginal douching & $43 / 987$ & $1.01(0.33-3.11)$ & & \\
\hline \multicolumn{5}{|l|}{ Condom use with clients/partners } \\
\hline Sometimes/Never & $31 / 799$ & 1.0 & & \\
\hline Always & $19 / 311$ & $1.75(0.92-3.33)$ & & \\
\hline \multicolumn{5}{|l|}{ Days since last menstruation ${ }^{c}$} \\
\hline$\leq 15$ & $27 / 503$ & 1.0 & & \\
\hline$>15$ & $14 / 415$ & $0.69(0.35-1.37)$ & & \\
\hline Bacterial vaginosis & $18 / 226$ & $2.11(1.12-4.00)$ & $2.17(1.13-4.18)$ & 0.02 \\
\hline Trichomonas vaginalis & $1 / 30$ & $1.18(0.13-10.53)$ & & \\
\hline Genital ulceration & $5 / 23$ & $4.66(1.55-14.03)$ & $3.29(1.13-9.55)$ & 0.03 \\
\hline \multicolumn{5}{|l|}{ 2. Among HIV-1 positive women only: } \\
\hline On HAART at prior visit & $15 / 94$ & $1.39(0.66-2.95)$ & $1.50(0.61-3.70)$ & 0.38 \\
\hline Highest $\log _{10}$ viral load in the past 3 years & & $1.35(0.99-1.83)$ & $1.13(0.78-1.65)$ & 0.51 \\
\hline CD4+ count at prior visit (per 100 cells $/ \mu \mathrm{L}$ increase) & & $0.73(0.57-0.93)$ & $0.79(0.61-1.02)$ & 0.07 \\
\hline
\end{tabular}

$\mathrm{HR}$, hazard ratio; $\mathrm{Cl}$, confidence interval; HAART: highly active antiretroviral therapy.

${ }^{a}$ Determined by Cox regression with shared frailty; ${ }^{\text {b }}$ Adjusted for HIV-1 serostatus and nadir CD4+ count, age group, educational status, smoking, history of pregnancy and HSV-2 serostatus at enrolment, and concurrent number of weekly sex partners, contraception, genital ulcerations and bacterial vaginosis;

' Women with amenorrhea and menopause were excluded from this group.

As in studies in developed countries, HIV-1 infection and immune function, as measured by nadir CD4+ count, were the most powerful predictors of incident and persistent GWs, $[13,15]$ even after adjusting for the presence of HPV. Although only partially understood, GW regression is thought to be dependent upon the cell-mediated immune response; CD4+ T-lymphocytes have been shown to be present in large numbers in the stroma under the lesions and in the regressing warts themselves, but their role in clearance has not been entirely elucidated [12,25]. In studies of canine oral papillomavirus, it is the response of $\mathrm{CD} 4+$ cells to viral 
Table 3 Associations between cervical HPV DNA, HIV-1 serostatus and cytology and incident genital warts among a sub-group of 306 women

\begin{tabular}{|c|c|c|c|c|}
\hline Characteristic & Number of events/person-years & Unadjusted $\mathrm{HR}^{\mathrm{a}}(95 \% \mathrm{Cl})$ & Adjusted $\mathrm{HR}^{\mathrm{b}}(95 \% \mathrm{Cl})$ & P-value \\
\hline \multicolumn{5}{|l|}{ Cervical HPV DNA at baseline } \\
\hline \multicolumn{5}{|l|}{ HPV-6 positive, yes vs. no } \\
\hline Effect in $1^{\text {st }}$ year of follow-up & $4 / 17$ & $8.67(1.86-40.40)$ & $9.09(1.75-47.29)$ & 0.009 \\
\hline Effect after $1^{\text {st }}$ year of follow-up & $1 / 12$ & $0.12(0.03-0.54)$ & $0.11(0.02-0.57)$ & 0.009 \\
\hline HPV-11 positive, yes vs. no & $1 / 21$ & $0.74(0.07-7.58)$ & $1.17(0.11-12.37)$ & 0.89 \\
\hline HPV-52 positive, yes vs. no & $9 / 50$ & $3.73(1.28-10.83)$ & $3.81(0.90-16.23)$ & 0.07 \\
\hline Other HPV types, negative for types $6,11,52$ & $19 / 226$ & $1.48(0.64-3.45)$ & $2.64(0.62-11.33)$ & 0.19 \\
\hline \multicolumn{5}{|l|}{ Cervical cytology at baseline $(N=296)$} \\
\hline Normal & $9 / 369$ & 1.0 & 1.0 & \\
\hline ASCUS/LSIL/HSIL & $23 / 134$ & $7.38(3.10-17.56)$ & $3.05(1.17-7.92)$ & 0.02 \\
\hline \multicolumn{5}{|l|}{ HIV status, nadir CD4+ count } \\
\hline HIV seronegative & $4 / 289$ & & 1.0 & \\
\hline HIV-1+, CD4 > 200cells/uL & $11 / 119$ & & $3.22(0.71-14.59)$ & 0.13 \\
\hline HIV- $1+$, CD4 $\leq 200$ cells $/ \mu \mathrm{L}$ & $18 / 79$ & & $10.94(2.60-46.12)$ & 0.001 \\
\hline
\end{tabular}

Note. HR: hazard ratio; Cl, confidence interval; ASCUS, atypical squamous changes of unknown significance; LSIL/HSIL, low/high squamous intraepithelial lesions. ${ }^{a}$ Determined by Cox regression with shared frailty; ${ }^{b}$ Model also included age group, history of pregnancy, history of smoking, hormonal contraception, education less than or greater than primary and number of sexual partners in past week. For those factors not conforming to proportional hazards, a parameter was added to determine the impact in the first year of follow-up compared to after one year.

proteins E6 and E7 that is responsible for regression of lesions [26]. The strong association between concurrent $\mathrm{BV}$ and genital ulceration and incident GWs supports a common determinant. There is good evidence supporting the role of the vaginal flora in both susceptibility to and clearance of infections, as HPV infects via microabrasions in the genital mucosa [27].

This is the first study to evaluate the impact of HAART on GWs in women in Africa. We did not detect any protective effect of HAART on incidence or persistence, despite the overall excellent adherence achieved in this cohort [28]. The burden of HR-HPV was recently shown to be reduced by effective HAART, [29] but the impact on LR-HPV is unknown, and its effect on GWs varies between studies $[3,15]$. However, our interpretation of these results is limited by the relatively small number of visits for women on HAART, and the partial data on concurrent CD4+ count and HIV-1 viral loads.

We identified a strong association between detection of cervical HPV-6 DNA and incident GWs in the first year of follow-up. Our data also support studies demonstrating a relative lack of epidemiological contribution of HPV-11 in GWs [7,30]. HPV-52 has been identified as one of the types most commonly identified in GWs in conjunction with HPV-6 in Australia [7]. Furthermore, a study of HPV in GWs in France demonstrated that 6.4\% of patients with GWs had HPV-52 on cytobrush sampling [6]. It is probable that cervical HPV was only partially representative of causative genotypes for GWs; the trend towards an increase in GWs in women infected with other types of HPV could reflect local but undetected infection with HPV-6 or 11. Furthermore, the small number of women infected with HPV-11 limits the power of this study to detect an association. However, as there are few studies examining the distribution of HPV in GWs in Africa, it is possible that this reflects a different epidemiology of HPV in this region compared to other settings. Further studies with larger numbers of women and direct sampling of warts for HPV types are required to better understand this relationship.

Study limitations include the varying time between visits, and the broad categorization of anatomical location which might have led to undetected new GWs and thus an underestimate of incidence. Although rare in this setting, it is also possible that some women sought treatment for GWs elsewhere, which may have resulted in underestimates of GW persistence.

\section{Conclusions}

This is the first study to examine the natural history of genital warts in African women and the impact of HIV1 infection and HAART. This high-risk population with high HIV prevalence and GW incidence and little access to ablative therapy may contribute more to HPV transmission and suffer disproportionately from the consequences of HPV infection. We have demonstrated a high incidence of genital warts in this population, and a very strong association with immune suppression from HIV-1 infection; there was no protective effect from HAART. This and other epidemiological studies of HPV types in different populations should inform further vaccine development designed for African women. 


\section{Acknowledgements}

This study was funded by France's Agence Nationale de Recherches sur le SIDA et les Hépatites (ANRS). Additional financial support was provided through the UK's Department for International Development (DFID)-funded Knowledge Programme on HIV/AIDS \& STI and the Research Programme Consortium on Research and Capacity Building in Sexual \& Reproductive Health and HIV in Developing Countries.

We wish to thank the women and the organisations of persons living with HIV/AIDS ('Yérelon', 'Espoir et Vie', Centre 'Solidarité Action Sociale' and 'Espoir pour Demain') who participated in this study; and staff at Service d'Hygiène, Bobo-Dioulasso, Burkina Faso. We also wish to thank Professor Charles Lacey (Hull York Medical School, York, UK) for his critical evaluation of this manuscript.

\section{* Composition of the Yérelon study group}

Eloi Bahembera, Abdramane Berthée, Minata Coulibaly, Marie-Christine Defer, Ramata Diallo, Didier Djagbaré, Charlotte Huet, Issouf Konaté, Florent KyDama, Gilles T. M'Boutiki, Nicolas Méda, Inès Millogo, Nicolas Nagot, Abdoulaye Ouédraogo, Djénéba Ouédraogo, Francois Rouet, Anselme Sanon, Haoua Sawadogo, Roselyne Vallo, and Laurence Vergne [deceased January 2007] (Centre Muraz, Bobo-Dioulasso, Burkina Faso); Philippe Mayaud, Nicolas Nagot, and Helen A. Weiss (London School of Hygiene and Tropical Medicine, London, UK); Pierre Becquart, Vincent Foulongne, Michel Segondy, and Philippe Van de Perre, (Université Montpellier 1, and CHU Montpellier, Montpellier, France); Jean-Baptiste Andonaba and Adrien Sawadogo (University Hospital of Bobo-Dioulasso, Burkina Faso).

\section{Author details}

${ }^{1}$ London School of Hygiene \& Tropical Medicine, London, UK. ${ }^{2}$ Centre Muraz, Bobo-Dioulasso, Burkina Faso. ${ }^{3}$ Université Montpellier 1, EA 4205 «

Transmission, Pathogenèse et Prévention de l'Infection par le VIH »; and CHU Montpellier, Laboratoire de Bactériologie-Virologie and Département d'Information Médicale, Montpellier, France.

\section{Authors' contributions}

All authors have read and approved the final manuscript. AL contributed to the study design, data/statistical analyses and the drafting of the manuscript. TC contributed to the statistical analyses and interpretation of results, and the drafting of the manuscript. IK contributed to the study design and data collection, and drafting of the manuscript. NN contributed to the study design and data collection, and the drafting of the manuscript. AO contributed to the study design, data management and the drafting of the manuscript. $\mathrm{CH}$ contributed to the study design, data analyses and the drafting of the manuscript. MD-R performed the collection and processing of the HPV samples and contributed to the drafting of the manuscript. MS contributed to the study design, the data analyses and the interpretation of results, and the drafting of the manuscript. PVdP contributed to the study design, the interpretation of results, and the drafting of the manuscript. PM was the lead investigator of this project, and contributed to the analyses, interpretation of results, and drafting of the manuscript.

\section{Competing interests}

The authors declare that they have no competing interests.

Received: 3 August 2010 Accepted: 20 January 2011

Published: 20 January 2011

\section{References}

1. Burchell AN, Winer RL, de Sanjose S, Franco EL: Chapter 6: Epidemiology and transmission dynamics of genital HPV infection. Vaccine 2006, 24(Suppl 3):S52-61.

2. Ho GY, Bierman R, Beardsley L, Chang CJ, Burk RD: Natural history of cervicovaginal papillomavirus infection in young women. $N$ Engl I Med 1998, 338:423-428

3. Massad LS, Silverberg MJ, Springer G, Minkoff H, Hessol N, Palefsky JM Strickler HD, Levine AM, Sacks HS, Moxley M, Heather Watts D: Effect of antiretroviral therapy on the incidence of genital warts and vulvar neoplasia among women with the human immunodeficiency virus. Am J Obstet Gynecol 2004, 190:1241-1248.

4. Moscicki AB, Ellenberg JH, Farhat $\mathrm{S}, \mathrm{Xu} \mathrm{J}$ : Persistence of human papillomavirus infection in HIV-infected and -uninfected adolescent girls: risk factors and differences, by phylogenetic type. J Infect Dis 2004, 190:37-45.

5. Roman A, Fife KH: Human papillomaviruses: are we ready to type? Clin Microbiol Rev 1989, 2:166-190.

6. Aubin F, Pretet JL, Jacquard AC, Saunier M, Carcopino X, Jaroud F, Pradat P, Soubeyrand B, Leocmach Y, Mougin C, Riethmuller D: Human papillomavirus genotype distribution in external acuminata condylomata: a Large French National Study (EDiTH IV). Clin Infect Dis 2008, 47:610-615.

7. Garland SM, Steben M, Sings HL, James M, Lu S, Railkar R, Barr E, Haupt RM, Joura EA: Natural history of genital warts: analysis of the placebo arm of 2 randomized phase III trials of a quadrivalent human papillomavirus (types 6, 11, 16, and 18) vaccine. J Infect Dis 2009, 199:805-814.

8. Wall SR, Scherf CF, Morison L, Hart KW, West B, Ekpo G, Fiander AN, Man S, Gelder CM, Walraven G, Borysiewicz LK: Cervical human papillomavirus infection and squamous intraepithelial lesions in rural Gambia, West Africa: viral sequence analysis and epidemiology. Br J Cancer 2005, 93:1068-1076.

9. Mayaud P, Gill DK, Weiss HA, Uledi E, Kopwe L, Todd J, ka-Gina G, Grosskurth H, Hayes RJ, Mabey DC, Lacey CJ: The interrelation of HIV, cervical human papillomavirus, and neoplasia among antenatal clinic attenders in Tanzania. Sex Transm Infect 2001, 77:248-254.

10. Didelot-Rousseau MN, Nagot N, Costes-Martineau V, Valles X, Ouedraogo A, Konate I, Weiss HA, Van de Perre P, Mayaud P, Segondy M: Human papillomavirus genotype distribution and cervical squamous intraepithelial lesions among high-risk women with and without HIV-1 infection in Burkina Faso. Br J Cancer 2006, 95:355-362.

11. Chaturvedi AK, Madeleine MM, Biggar RJ, Engels EA: Risk of human papillomavirus-associated cancers among persons with AIDS. J Nat/ Cancer Inst 2009, 101:1120-1130.

12. Lacey CJ: Therapy for genital human papillomavirus-related disease. J Clin Virol 2005, 32(Suppl 1):S82-90.

13. Silverberg MJ, Ahdieh L, Munoz A, Anastos K, Burk RD, Cu-Uvin S, Duerr A, Greenblatt RM, Klein RS, Massad S, et al: The impact of HIV infection and immunodeficiency on human papillomavirus type 6 or 11 infection and on genital warts. Sex Transm Dis 2002, 29:427-435.

14. Heard I, Tassie JM, Schmitz V, Mandelbrot L, Kazatchkine MD, Orth G: Increased risk of cervical disease among human immunodeficiency virus-infected women with severe immunosuppression and high human papillomavirus load(1). Obstet Gynecol 2000, 96:403-409.

15. Dolev JC, Maurer T, Springer G, Glesby MJ, Minkoff H, Connell C, Young M, Schowalter K, Cox C, Hessol NA: Incidence and risk factors for verrucae in women. AIDS 2008, 22:1213-1219.

16. World Health Organization. Dept. of HIV/AIDS. Interim WHO Antiretroviral Treatment Working Group: Scaling up antiretroviral therapy in resourcelimited settings : guidelines for a public health approach Geneva: World Health Organization; 2002.

17. Nugent RP, Krohn MA, Hillier SL: Reliability of diagnosing bacterial vaginosis is improved by a standardized method of gram stain interpretation. J Clin Microbiol 1991, 29:297-301.

18. Nagot N, Ouedraogo A, Ouangre A, Cartoux M, Defer MC, Meda N, Van de Perre $P$ : Is sexually transmitted infection management among sex workers still able to mitigate the spread of HIV infection in West Africa? J Acquir Immune Defic Syndr 2005, 39:454-458.

19. Rouet F, Chaix ML, Nerrienet E, Ngo-Giang-Huong N, Plantier JC, Burgard M, Peeters M, Damond F, Ekouevi DK, Msellati P, et al: Impact of HIV-1 genetic diversity on plasma HIV-1 RNA Quantification: usefulness of the Agence Nationale de Recherches sur le SIDA second-generation long terminal repeat-based real-time reverse transcriptase polymerase chain reaction test. J Acquir Immune Defic Syndr 2007, 45:380-388.

20. Didelot-Rousseau MN, Courgnaud V, Nagot N, Ouedraogo A, Konate I, Mayaud P, Weiss H, Van de Perre P, Segondy M: Comparison of INNO-LiPA HPV Genotyping v2 with PCR product subcloning and sequencing for identification of genital human papillomavirus genotypes in African women. J Virol Methods 2006, 135:181-185.

21. Smith JH: Bethesda 2001. Cytopathology 2002, 13:4-10.

22. Xue X, Gange SJ, Zhong Y, Burk RD, Minkoff H, Massad LS, Watts DH, Kuniholm MH, Anastos K, Levine AM, et al: Marginal and mixed-effects models in the analysis of human papillomavirus natural history data. Cancer Epidemiol Biomarkers Prev 2010, 19:159-169. 
23. Low A, Didelot-Rousseau MN, Nagot N, Ouedraougo A, Clayton T, Konate I, Van de Perre P, Segondy M, Mayaud P: Cervical infection with human papillomavirus (HPV) 6 or 11 in high-risk women in Burkina Faso. Sex Transm Infect 2010.

24. Mayaud P, Weiss HA, Lacey CJ, Gill DK, Mabey DC: Genital human papillomavirus genotypes in northwestern Tanzania. J Clin Microbiol 2003, 41:4451-4453.

25. Hong K, Greer CE, Ketter N, Van Nest G, Paliard X: Isolation and characterization of human papillomavirus type 6-specific T cells infiltrating genital warts. J Virol 1997, 71:6427-6432.

26. Jain S, Moore RA, Anderson DM, Gough GW, Stanley MA: Cell-mediated immune responses to COPV early proteins. Virology 2006, 356:23-34.

27. Watts DH, Fazzari M, Minkoff H, Hillier SL, Sha B, Glesby M, Levine AM, Burk R, Palefsky JM, Moxley M, et al: Effects of bacterial vaginosis and other genital infections on the natural history of human papillomavirus infection in HIV-1-infected and high-risk HIV-1-uninfected women. J Infect Dis 2005, 191:1129-1139.

28. Huet C, Ouedraogo A, Konate I, Traore I, Rouet F, Ouiminga A, A S, Mayaud P, Van de Perre P, Nagot N: Feasibility and efficacy of highly active antiretroviral therapy among high-risk and marginalised HIV-1 infected women in West Africa. Book Feasibility and efficacy of highly active antiretroviral therapy among high-risk and marginalised HIV-1 infected women in West Africa City; 2009.

29. Minkoff H, Zhong Y, Burk RD, Palefsky JM, Xue X, Watts DH, Levine AM, Wright RL, Colie C, D'Souza G, et al: Influence of adherent and effective antiretroviral therapy use on human papillomavirus infection and squamous intraepithelial lesions in human immunodeficiency viruspositive women. J Infect Dis 2010, 201:681-690.

30. Vandepapeliere $\mathrm{P}$, Barrasso R, Meijer CJ, Walboomers JM, Wettendorff $M$, Stanberry LR, Lacey CJ: Randomized controlled trial of an adjuvanted human papillomavirus (HPV) type 6 L2E7 vaccine: infection of external anogenital warts with multiple HPV types and failure of therapeutic vaccination. J Infect Dis 2005, 192:2099-2107.

\section{Pre-publication history}

The pre-publication history for this paper can be accessed here: http://www.biomedcentral.com/1471-2334/11/20/prepub

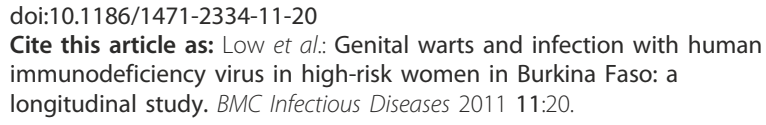

\section{Submit your next manuscript to BioMed Central and take full advantage of:}

- Convenient online submission

- Thorough peer review

- No space constraints or color figure charges

- Immediate publication on acceptance

- Inclusion in PubMed, CAS, Scopus and Google Scholar

- Research which is freely available for redistribution

Submit your manuscript at www.biomedcentral.com/submit 